\title{
Kesulitan Mahasiswa Dalam Memahami Konsep Kinematika Gerak 1 Dimensi
}

\author{
Abu Zainuddin ${ }^{1}$, Sentot Kusairi ${ }^{2}$, Siti Zulaikah ${ }^{2}$ \\ ${ }^{1}$ Pendidikan Fisika-Universitas Negeri Surabaya \\ ${ }^{2}$ Pendidikan Fisika-Universitas Negeri Malang
}

\begin{tabular}{l} 
INFO ARTIKEL \\
\hline Riwayat Artikel: \\
Diterima: 06-07-2018 \\
Disetujui: $18-01-2019$ \\
\hline
\end{tabular}

Kata kunci:

student difficulties;

kinematics;

kesulitan mahasiswa;

kinematika

\author{
Alamat Korespondensi: \\ Abu Zainuddin \\ Pendidikan Fisika \\ Universitas Negeri Surabaya \\ Jalan Ketintang, Surabaya 6023 \\ E-mail: abuzainuddin@unesa.ac.id
}

\begin{abstract}
This study aims to reveal the difficulties of students in understanding the concept of 1 Dimensional motion kinematics. The research subjects were 38 undergraduate students of UNESA Physics Education semester V class A. The research method used a survey using instruments in the form of 20 reasoned multiple choice questions on the topic of Newtonian Mechanics. In this article the discussion is focused on questions number 2 and number 4 because it indicates the difficulties of students in understanding the concept of 1-dimensional kinematics. From the results of the analysis of the reasons for student answers it is known that students experience difficulties, namely, difficulties in distinguishing position, displacement or distance; difficulty interpreting negative acceleration and is always considered a slowdown.
\end{abstract}

ABSTRAK

\begin{abstract}
Abstrak: Penelitian ini bertujuan untuk mengungkap kesulitan mahasiswa dalam memahami konsep kinematika gerak 1 Dimensi. Subjek penelitian adalah 38 mahasiswa S1 Pendidikan Fisika UNESA semester V kelas A. Metode penelitian menggunakan survei dengan menggunakan instrumen berupa 20 soal pilihan ganda beralasan pada topik Mekanika Newton. Pada artikel ini pembahasan difokuskan pada soal nomor 2 dan nomor 4 karena mengindikasikan kesulitan mahasiswa dalam memahami konsep kinematika 1 dimensi. Dari hasil analisis alasan jawaban mahasiswa diketahui bahwa mahasiswa mengalami kesulitan yakni, kesulitan dalam membedakan posisi, perpindahan atau jarak; kesulitan memaknai percepatan negatif dan selalu dianggap sebagai perlambatan
\end{abstract}

Pemahaman konsep sangat penting dikuasai oleh calon guru fisika sebelum terjun mengajar di kelas. Sebagai sutradara dalam pembelajaran, seorang pendidik dituntut mampu merancang pembelajaran yang tepat. Merancang pembelajaran tidak dapat lepas dari pemahaman konsep yang mumpuni. Rancangan pembelajaran yang kurang tepat akan berdampak pada kesalahan konsep yang dialami oleh peserta didik. Kesalahan konsep pada level pendidikan yang lebih bawah akan dibawa terus pada level diatasnya sampai didapatkan solusi dari kesalahan tersebut. Jika tidak ditemukan solusi maka kesulitan belajar akan dihadapi oleh peserta didik. Mengetahui pemahaman konsep sekaligus untuk mendeteksi kesulitan yang masih dihadapi oleh mahasiswa. Beberapa dekade terakhir fokus penelitian lebih pada kesulitan mahasiswa dalam menjelaskan fenomena, memahami konsep, dan memecahkan persoalan fisika. Docktor \& Mestre (2014) menyatakan bahwa terdapat tiga teori untuk menjelaskan kesulitan tersebut. Pertama, teori miskonsepsi memandang bahwa kesulitan mahasiswa dikarenakan mereka telah memiliki pengetahuan yang tidak sesuai dengan konsep sains (Baser, 2006). Kedua, teori resource atau knowledge in pieces memandang bahwa mahasiswa kesulitan menemukan permasalahan bahkan sering gagal dalam mengaktivasi pengetahuan yang relevan terhadap permasalahan disebabkan mereka tidak memiliki pengetahuan yang utuh walau sebenarnya pengetahuannya benar. Ketiga, teori kategori ontologis yang memandang bahwa kesulitan mahasiswa dalam memahami konsep fisis dikarenakan kesalahan dalam menggolongkan pengetahuan.

Dalam beberapa dekade terakhir banyak peneliti yang memandang bahwa kesulitan yang dialami oleh mahasiswa disebabkan oleh adanya kekeliruan pemahaman atau miskonsepsi (Halloun \& Hestenes, 1987; McDermott, 1987; Limon, 2001). Menurut teori miskonsepsi, pemahaman konsep mahasiswa dibangun berdasarkan teori naive (Sugara et al., 2017). Kekeliruan mahasiswa ini banyak disebabkan karena pengalaman individual mahasiswa dalam mengamati kehidupan sehari-hari. Dari pengamatan tersebut kemudian dibangun sebuah pemahaman yang hanya benar dalam konteks yang sempit namun sering kali digeneralisasikan oleh mereka dalam konteks yang tidak sesuai (Taqwa, 2017; Halloun \& Hestenes, 1985). Pemahaman yang 
dibangun sendiri oleh mereka justru lebih dipercaya dan retensi untuk diubah (Berek, 2016) sehingga ketika mahasiswa menyelesaikan persoalan, pengetahuan yang keliru tersebut cenderung konsisten digunakan.

Berbeda dengan teori miskonsepsi, pandangan teori resource beranggapan bahwa kesulitan mahasiswa dalam memahami konsep bukan disebabkan karena mahasiswa tidak memiliki pengetahuan yang benar, namun pengetahuan yang benar tersebut sering kali tidak terangkat saat menyelesaikan persoalan. Menurut teori resource, pandangan teori miskonsepsi cenderung terbatas (Hammer, 1996; Hammer, 200). Pertama, menurut teori miskonsepsi mahasiswa cenderung konsisten menggunakan pengetahuan yang salah dalam menyelesaikan bermacam persoalan yang disajikan dalam konteks yang beragam (Bektasli, 2011). Namun, temuan menunjukkan bahwa pada saat siswa diberikan soal yang berbeda konteks akan cenderung memberikan alasan yang berbeda pula (Bektasli, 2011). Hal tersebut jelas kontras dengan pandangan teori miskonsepsi. Kedua, miskonsepsi dibentuk berdasarkan pengalaman dan interaksi mahasiswa dengan lingkungan, namun miskonsepsi menjelaskan bagaimana pengetahuan yang keliru tersebut dapat berubah menjadi konsep yang benar sesuai pandangan ilmuan (Docktor $\&$ Mestre, 2014).

Penelitian ini bertujuan untuk mengidentifikasi kesulitan mahasiswa dalam memahami konsep kinematika gerak 1 dimensi. Hal ini penting dilakukan untuk melihat keutuhan pemahaman mahasiswa dalam memahami ide-ide pokok dalam kinematika. Oleh karenanya, pembahasan dalam artikel ini dilakukan dengan mengidentifikasi resouce mahasiswa.

\section{METODE}

Penelitian ini merupakan penelitian deskriptif dengan menggunakan metode survei. Responsen penelitain adalah sejumlah 38 mahasiswa S1 Pendidikan Fisika Universitas Negeri Surabaya semester V. Alat ukur yang digunakan berupa 20 soal pilihan ganda beralasan yang berisi soal-soal untuk mengukur penguasaan konsep mekanika Newtonan oleh mahasiswa (10 butir soal kinematika dan 10 butir soal dinamika partikel). Dari 10 soal kinematika 6 soal di antaranya adalah soal kinematika gerak 1 Dimensi, terdiri atas dua soal bentuk verbal, dua soal bentuk diagram, dan dua soal persamaan matematis.

Data yang diperoleh dari penelitian ini adalah data opsi jawaban yang dipilih oleh mahasiswa dan alasan yang diberikan dalam menjawab soal tes. Pembahasan hanya difokuskan pada dua butir soal yakni nomor 2 dan nomor 4 karena merupakan soal yang sulit dijawab oleh mahasiswa. Hal tersebut diindikasi dengan banyak mahasiswa yang memilih opsi salah dan memberikan alasan yang tidak sesuai dengan konsep.

Analisis data dilakukan baik secara kualitatif maupun kuantitatif. Analisis data kuantitatif dilakukan dengan melihat pilihan opsi jawaban oleh mahasiswa yang kemudian dikelompokkan berdasarkan kesamaan pilihan opsi jawaban oleh mahasiswa. Untuk mempermudah pembahasan, data ditampilkan dalam tabel distribusi pilihan opsi jawaban. Analisis data kualitatif dilakukan dengan mereduksi data, menyajikan data, dan menarik kesimpulan (Taqwa et al., 2007b; Sugiyono, 2014).

\section{HASIL}

\section{Deskripsi Kesulitan Mahasiswa dalam Memahami Konsep Kinematika Gerak 1 Dimensi}

Butir soal nomor 2 dapat dilihat pada Gambar 1, sedangkan butir soal nomor 4 dapat dilihat pada Gambar 2. Distribusi jumlah jawaban mahasiswa untuk masing-masing soal dapat dilihat pada Tabel 1 dan 2.

Sebuah objek bergerak menempuh lintasan lurus dengan persamaan posisi sebagai fungsi waktu dinyatakan sebagai $x(t)=2+4 t-t^{2} \cdot \vec{x}$ dalam meter dan $t$ dalam sekon. Tanda $(+)$ disepakati sebagai arah vektor ke kanan dan tanda (-) sebagai arah vektor ke kiri. Selama bergerak dalam selang waktu $0 \mathrm{~s} \leq t \leq 5 \mathrm{~s}$, pernyataan berikut yang benar adalah...

(A) Objek menempuh jarak 5 meter

(B) Objek menempuh jarak 13 meter

(C) Objek berpindah sejauh 3 meter ke arah kiri

(D) Objek berpindah sejauh 5 meter ke arah kiri

(E) Opsi (A) dan (C) benar

(F) Opsi (B) dan (D) benar (*)

\section{Gambar 1. Soal Gerak 1 Dimensi Nomor 2}

Tabel 1. Jumlah Mahasiswa Dalam Menjawab Soal Nomor 2

\begin{tabular}{ccc}
\hline \multirow{2}{*}{ Pilihan Jawaban } & \multicolumn{2}{c}{ Jumlah Mahasiswa } \\
\cline { 2 - 3 } & Angka & $\%$ \\
\hline A & 6 & 15.79 \\
B & 0 & 0.00 \\
C & 18 & 47.37 \\
D & 9 & 23.68 \\
E & 0 & 0.00 \\
F $^{*}$ & 5 & 13.16 \\
\hline
\end{tabular}


Tabel 1 menunjukkan bahwa hanya 13,16\% mahasiswa atau sejumlah 5 dari 38 mahasiswa yang menjawab benar. Sebanyak 33 mahasiswa $(86,84 \%)$ mahasiswa menjawab salah soal nomor 2. Kelompok mahasiswa yang menjawab salah terbagi atas 6 mahasiswa memilih jawaban A, 9 mahasiswa memilih jawaban D, dan 18 mahasiswa memilih jawaban C serta tidak satupun yang memilih jawaban B dan E.

Butir soal nomor 2 disajikan dalam bentuk persamaan gerak berupa persamaan posisi pada sumbu - x sebagai fungsi waktu. Penjelasan soal sudah cukup lengkap mengenai arah vektor (+/-), yaitu (+) ke kanan dan (-) ke kiri. Bentuk lintasan dan nama persamaan gerak juga sudah disebutkan dengan jelas. Namun, ketika menjawab soal dan memberikan alasan, mahasiswa masih tampak kesulitan. Pilihan jawaban yang benar adalah $\mathrm{F}$ yaitu pilihan jawaban B dan D benar.

Sebanyak 22 mahasiswa memilih jawaban C. Dilihat dari alasan jawaban, mereka langsung mensubstitusi nilai $\mathrm{t}=5 \mathrm{~s}$ ke persamaan posisi $x(t)=\left(2+4 t-t^{2}\right) m$ sehingga didapat $\mathrm{x}(5)=-3 \mathrm{~m}$ sehingga mereka menyimpulkan bahwa objek berpindah sejauh $3 \mathrm{~m}$ ke arah kiri sesuai jawaban C. Nampak bahwa mahasiswa mengalami kesulitan dalam membedakan antara posisi dan perpindahan. Mereka menganggap bahwa persamaan matematis pada soal nomor 2 adalah persamaan perpindahan.

Kelompok lain yang terdiri dari sembilan mahasiswa memilih jawaban D. Berdasarkan alasan jawaban yang mereka tulis mereka menentukan perpindahan dengan menghitung selisih posisi saat $\mathrm{t}=5 \mathrm{~s}$ dan $\mathrm{t}=0 \mathrm{~s}$ didapat $\Delta x=\mathrm{x}(5)-\mathrm{x}(0)=-5 \mathrm{~m}$, kemudian mereka menyimpulkan bahwa objek berpindah sejauh $5 \mathrm{~m}$ ke arah kiri. Secara konseptual kelompok ini sudah dapat membedakan posisi dan perpindahan serta dapat menggunakan persamaan posisi untuk menghitung besar perpindahan. Namun mereka kesulitan dalam menentukan jarak yang ditempuh objek sebesar $13 \mathrm{~m}$ sesuai pilhan jawaban B.

Sementara itu, 6 mahasiswa memilih jawaban A. Dilihat dari alasan jawaban , mereka juga menggunakan perhitungan $\Delta x=\mathrm{x}(5)-\mathrm{x}(0)=-5 \mathrm{~m}$ dan mereka menyimpulkan bahwa objek menempuh jarak $5 \mathrm{~m}$. Kelompok ini kesulitan dalam membedakan antara jarak dan perpindahan. Tanda (-) mereka anggap sebagai arah kiri, sehingga menurut mereka benda menempuh jarak $5 \mathrm{~m}$ ke erah kiri. Dilihat dari tabel 1 tidak ada satupun yang menjawab B, berarti selain lima mahasiswa yang menjawab benar F, tak satupun yang dapat menghitung nilai jarak dari persamaan posisi yang diberikan dalam soal.

Sebuah objek bergerak menempuh lintasan lurus dengan persamaan posisi sebagai fungsi waktu dinyatakan sebagai
$\vec{x}(t)=2+4 t-t^{2} . \vec{x}$ dalam meter dan $t$ dalam sekon. Tanda ( + ) disepakati sebagai arah vektor ke kanan dan tanda
(-) sebagai arah vektor ke kiri. Pernyataan yang benar terkait gerak objek dalam selang waktu $2 \mathrm{~s} \leq t \leq 3 \mathrm{~s}$ adalah...
(A) Benda bergerak ke kanan sambil diperlambat, dengan laju berkurang $2 \mathrm{~m} / \mathrm{s}$ tiap detik
(B) Benda bergerak ke kiri sambil diperlambat, dengan laju berkurang $2 \mathrm{~m} / \mathrm{s}$ tiap detik
(C) Benda bergerak ke kanan sambil dipercepat, dengan laju bertambah $2 \mathrm{~m} / \mathrm{s}$ tiap detik
(D) Benda bergerak ke kiri sambil dipercepat, dengan laju bertambah $2 \mathrm{~m} / \mathrm{s}$ tiap detik $(*)$
(E) Tidak ada opsi benar, benda bergerak ke kanan kemudian berbalik ke kiri, dengan selalu diperlambat

Gambar 2. Soal Gerak 1 Dimensi Nomor 4

Tabel 2. Jumlah Mahasiswa Dalam Menjawab Soal Nomor 4

\begin{tabular}{ccr}
\hline \multirow{2}{*}{ Pilihan Jawaban } & \multicolumn{2}{c}{ Jumlah Mahasiswa } \\
\cline { 2 - 3 } & Angka & \multicolumn{1}{c}{$\%$} \\
\hline A & 6 & 15.79 \\
B & 26 & 68.42 \\
C & 2 & 5.26 \\
D $^{*}$ & 3 & 7.89 \\
E & 1 & 2.63 \\
\hline
\end{tabular}

Tabel 2 menunjukkan bahwa hanya 3 mahasiswa (7,89\%) yang menjawab benar D. Selebihnya, 35 mahasiswa(92,11\%) memberikan jawaban salah ketika menjawab soal nomor 4. Jumlah terbanyak adalah menjawab B sejumlah 26 mahasiswa,. Selebihnya 6 mahasiwa memilih jawaban A, 2 mahasiwa menjawab C, dan 1 mahasiswa menjawab E.

Butir soal nomor 2 dan soal nomor 4 juga disajikan dalam bentuk persamaan matematis berupa persamaan posisi. Informasi yang disajikan soal juga cukup jelas mengenai jenis persamaan termasuk penjelasan tanda (+) merupakan arah kanan dan tanda (-) sebagai arah kiri. Soal nomor 4 meminta mahasiswa untuk menentukan pernyataan yang benar sesuai pilihan jawaban. Sebenarnya apa yang terjadi dengan objek pada interval waktu $2 \mathrm{~s} \leq t \leq 3$ sekon. Diberikan lima opsi pilihan jawaban untuk mengetahui pemahaman mahasiswa tentang konsep percepatan, khususnya memaknai percepatan negatif.

Sebanyak 26 mahasiswa $(68,42 \%)$ memilih jawaban B. Dilihat dari alasan jawaban yang mereka tulis ,ada dua kelompok jawaban. Pertama, mereka menurunkan persamaan posisi terhadap waktu dua kali $\left(a=\frac{d^{2} x}{d t^{2}}\right)$, sehingga didapat percepatan $\mathrm{a}=-2 \mathrm{~m} / \mathrm{s}^{2}$. Kedua, menentukan persamaan kecepatan dengan menurunkan persamaan posisi $\left(v=\frac{d x}{d t}\right)$, didapat $\mathrm{v}=4-$ $2 \mathrm{t}$, kemudian menentukan percepatan $\mathrm{a}=\frac{v(3)-v(2)}{3-2}=-2 \mathrm{~m} / \mathrm{s}$. Walaupun langkah mereka berbeda namun sama-sama mendapatkan nilai a $=-2 \mathrm{~m} / \mathrm{s}^{2}$, kemudian mereka menyimpulkan bahwa benda bergerak ke kiri sambil diperlambat, dengan laju berkurang 2 $\mathrm{m} / \mathrm{s}$ tiap detik. Sebanyak enam mahasiswa (15,78\%) mahasiswa yang memilih jawaban A menggunakan cara yang sama dengan 
kelompok yang memilih jawaban B dengan cara menurunkan persamaan posisi sebanyak dua kali sehingga didapat a $=-2 \mathrm{~m} / \mathrm{s}^{2}$. Mereka justru menyimpulkan bahwa benda bergerak ke kanan sambil diperlambat, dengan laju berkurang $2 \mathrm{~m} / \mathrm{s}$ tiap detik. Sementara itu, dua mahasiwa yang memilih jawaban $\mathrm{C}$ tanpa alasan jawaban yang kuat menyimpulkan bahwa benda bergerak ke kanan sambil dipercepat, dengan percepatan $2 \mathrm{~m} / \mathrm{s}$ tiap detik. Bahkan terdapat satu mahasiswa yang mengganggap tidak ada pilihan jawaban yang benar.

\section{PEMBAHASAN}

Berdasarkan hasil penelitian dapat diketahui bahwa mahasiswa mengalami kesulitan yang cukup mendasar dalam memahami konsep kinematika gerak 1 Dimensi. Apabila kita gabungkan kesulitan mahasiswa dalam memahami konsep posisi, perpindahan atau jarak, serta konsep percepatan, kita dapat menyatakan bahwa mahasiswa mengalami kesulitan ketika menghadapi soal dalam bentuk persamaan matematis. Disamping itu, konsep posisi, perpindahan, kecepatan, dan percepatan saling terkait. Keempatnya merupakan konsep mendasar dalam kinematika, sehingga kesalahan memahami satu konsep dalam kinematika akan berdampak pada kesalahan dalam konsep yang lain. Kesulitan yang dihadapi mahasiswa dapat dikategorikan sebagai resource atau knowledge in pieces yang disebabkan ketidakutuhan dalam pengetahuan tentang posisi, perpindahan atau jarak serta percepatan yang menyebabkan kekeliruan yang cenderung konsisten. Pemahaman yang dibangun sendiri oleh mereka justru lebih dipercaya dan retensi untuk diubah (Berek, 2016) sehingga ketika mahasiswa menyelesaikan persoalan, pengetahuan yang keliru tersebut cenderung konsisten digunakan. Penelitian ini bersesuaian dengan Docktor \& Mestre (2014) yang menyatakan bahwa terdapat tiga teori untuk menjelaskan kesulitan, salah satunya adalah teori resource atau knowledge in pieces, yang memandang bahwa mahasiswa kesulitan menemukan permasalahan bahkan sering gagal dalam mengaktivasi pengetahuan yang relevan terhadap permasalahan disebabkan mereka tidak memiliki pengetahuan yang utuh walau sebenarnya pengetahuannya benar.

Penyebab kesulitan mahasiswa dalam memahami konsep kinematika 1 dimensi dapat dijelaskan dalam dua alasan. Pertama, mayoritas mahasiswa yang mengalami kerancuan memaknai persamaan posisi sebagai persamaan perpindahan benda. walaupun pada kondisi tertentu besar perpindahan sama dengan jarak tempuh, yakni ketika benda bergerak lurus pada interval tertentu dalam sekali gerak tanpa mengubah arah gerak. Kerancuan berpikir mahasiswa yang berdampak menjadi kesulitan yang cukup berarti dalam memaknai persamaan gerak bukan tidak beralasan. Jika kita melihat dan mengkaji soal-soal di buku-buku fisika sekolah menengah, seringkali istilah kecepatan dipakai sebagai jarak tiap satuan waktu. Padahal seyogyanya harus konsisten dalam memahami besaran fisika, karena beda penyebutan nama besaran akan berimplikasi terhadap pemahaman yang salah di benak mahasiswa. Kebiasaan menjawab soal-soal di sekolah menengah terus terbawa sampai level perguruan tinggi, bahkan sampai semester V. Kegagalan dimasa sekolah dalam memahami konsep posisi, perpindahan atau jarak berdampak pada kesulitan dalam memahami konsep yang serupa di tingkat perguruan tinggi.

Kedua, kesulitan mahasiswa memahami percepatan negatif karena terbiasa memaknai percepatan negatif sebagai perlambatan. Kenyataannya hanya 3 dari 38 mahasiswa yang mampu menjawab benar. Selebihnya, sekalipun mereka benar dalam menentukan nilai percepatan sehingga didapat $\mathrm{a}=-2 \mathrm{~m} / \mathrm{s}^{2}$, namun mereka mengartikan bahwa tanda (-) menunjukkan adanya perlambatan. Memang tidaklah salah ketika benda sedang bergerak ke kanan (kecepatan ke kanan) dengan nilai kecepatan berkurang, maka akan muncul percepatan negatif (ke arah kiri) dan pada saat itu disebut sebagai perlambatan. Ketika benda bergerak ke kiri dengan nilai kecepatan yang bertambah, maka akan diperoleh percepatan negatif, namun bukan sebagai perlambatan tapi sebagai percepatan. Kerancuan pemahaman konsep yang terjadi disebabkan mereka sudah terbiasa sejak sekolah menengah memaknai percepatan negatif selalu sebagai perlambatan. Karena soal-soal di sekolah menengah terbiasa memberikan gambaran benda yang selalu bergerak ke kanan, dan jarang diberikan kasus soal benda yang bergerak ke kiri dengan arah percepatan juga ke kiri.

Hasil penelitian ini memberikan gambaran akan pentingnya strategi yang sesuai dan urutan pembelajaran yang tepat ketika mengajarkan konsep-konsep fundamental dalam kinematika gerak 1 Dimensi. Pembelajaran yang tepat tentang vektor juga sangat diperlukan karena sebagian besar besaran fisika adalah vektor. Sudah seharusnya penyelesaian soal besaran vektor menggunakan aturan vektor yang sesuai. Sekalipun gerak 1 Dimensi terkadang dikerjakan dengan cara skalar, tanpa memperhatikan arah gerak karena memang biasanya hanya pada satu arah. Namun kenyataannya, ketika diberikan soal yang mengandung perubahan arah gerak maka kesulitan akan muncul dan ini yang terjadi pada mayoritas mahasiswa S1 Pendidikan Fisika yang mengampu Mata kuliah Fisika Sekolah. Butuh latihan yang lebih banyak dalam menerjemahkan soal dari bentuk matematis ke dalam bentuk diagram. Pembelajaran yang melibatkan diagram gerak dapat menjadi alternatif pilihan.

Penelitian ini mampu mengungkap kesulitan yang dihadapi oleh mahasiswa dalam memahami konsep kinematika gerak 1 Dimensi, namun masih terdapat beberapa kendala. Pertama, soal kinematika 1 Dimensi yang diujikan terlalu sedikit sehingga kurang variatif. Oleh karena itu, perlu disiapkan soal dengan jumlah lebih banyak dan lebih variatif sehingga mampu mengungkap pemahaman konsep yang lebih mendalam. Kedua, subjek penelitian yang dipilih belum mewakili seluruh angkatan sehingga pada penelitian selanjutnya perlu dilakukan penelitian di setiap angkatan, sehingga profil pemahaman konsep mahasiwa materi kinematika gerak 1 Dimensi lebih tampak. 


\section{SIMPULAN}

Dari hasil dan pembahasan dapat disimpulkan bahwa mahasiswa kesulitan dalam memahami konsep kinematika gerak 1 Dimensi yang disajikan dalam bentuk persamaan matematis. Kesulitan tersebut, antara lain (1) mahasiswa sulit membedakan persamaan posisi dan perpindahan; (2) mahasiswa sulit dalam memahami percepatan negatif dan selalu dianggap sebagai perlambatan. Agar didapat pemahaman konsep dimensi kinematika 1 D yang lebih mendalam, soal yang disajikan lebih banyak dan variatif serta fokus hanya pada gerak 1 Dimensi. Kesulitan yang dihadapi mahasiswa dapat diatasi dengan strategi pembelajaran yang tepat dan urut. Butuh latihan lebih banyak menerjemahkan soal dalam bentuk matematis ke dalam bentuk diagram gerak.

\section{DAFTAR RUJUKAN}

Baser, M. (2006). Fostering Conceptual Change By Cognitive Conflict Based Instrustion on Students' Understanding of Heat And Temperature Concepts. Eurasia Journal of Mathematics, Science, and Technology Education, 2(2), 96-114..

Docktor, J. L. \& Mestre, J. P. (2014). Synthesis of discipline-based education research in physics. Physical Review Special Topik - Physics Education Research, 10, 020119.

Halloun, I \& Hestenes, D. (1987). The Relation between Problem Categorization and Problem Solving Among Expert and Novice. Memory and Cognition, 17(5), 627-638.

Limon, M. (2001). On the Cognitive Conflict as an Instructional Strategy for Conceptual Change: A Critical Appraisal. Learning and Instruction, 1(11), 357-380.

McDermott, L. C., Rosenquist, M. L., \& Van Zee., E. H. (1987). Student Difficulties in Connecting Graphs and Physics: Example from Kinematics, Am. J. Phys, 55, 503-513.

Flores, S., Kanim, S.E., \& Kautz, C.H. (2004). Student Use of Vector in Introductory Mechanics. American Journal of Physics, 72 (4): 460-468.

Berek, F. X., Sutopo, \& Munzil. (2016). Concept Enhancement of Junior High School Students in Hydrostatic Presure and Archimedes Law by Predict-Observe-Explain Strategy. Jurnal Pendidikan IPA Indonesia, 5(2), 230 - 238.

Halloun, I. A., Hestenes, D. (1985). The initial knowledge state of college physics students. American Journal of Physics, 53(11), 1043-1055.

Sugiyono. (2014). Metode Penelitian Pendidikan Pendekatan Kuantitatif, Kualitatif dan R\&D. Bandung: Alfabeta.

Taqwa, M. R. A. (2017). Profil pemahaman konsep mahasiswa dalam menentukan arah resultan gaya. Prosiding Seminar Nasional Pendidikan Sains, Universitas Negeri Surabaya.

Taqwa, M. R. A., Hidayat, A., \& Sutopo. (2017a). Recitation Program Based on Multi Representation Needed to Increasing The Kinematics Conceptual Understanding. The 2nd International Seminar on Science Education, Graduate School Yogyakarta State University.

Taqwa, M. R. A., Hidayat, A., \& Sutopo. (2017b). Konsistensi Pemahaman Konsep Kecepatan dalam Berbagai Format Representasi. Jurnal Riset dan Kajian Pendidikan Fisika, 4(1), 31-39. 